\title{
Fenomenologia przebaczenia - moralny i metafizyczny wymiar przebaczenia
}

I odpuść nam nasze winy, jako i my odpuszczamy naszym winowajcom.

(Mt 6, 12)

Próba namysłu nad aktami przebaczenia nie jest zadaniem łatwym. Wydaje się, że nie ujawniają się w nim żadne prawidłowości. Jest ono i być powinno wydarzeniem nadzwyczajnym. Nie w tym sensie oczywiście, że może wydarzać się wyjątkowo, lecz w tym, że jest zawsze aktem, w którym należy uwzględnić konkretne okoliczności, i nie można z góry wybaczyć i prosić o wybaczenie wszelkich krzywd, jakie sami kiedykolwiek uczynimy i inni uczynią nam. Przebaczyć może tylko ten, kto był ofiarą krzywdy i złego czynu, i może to czynić tylko w konkretnych okolicznościach. Również dla współczesnego człowieka piąta prośba z Modlitwy Pańskiej jest błaganiem szczególnym. Jest taką nie tylko z tego powodu, że w niej właśnie - jak dowodził hrabia August Cieszkowski - najmocniej ukazuje się dwustronna relacja Boga i człowieka ${ }^{1}$. Łatwo bowiem dostrzec, że prośba o przebacze-

* Prof. zw. dr hab. Marek Szulakiewicz jest kierownikiem Katedry Teorii Kultury i Religii na Wydziale Politologii i Studiów Międzynarodowych Uniwersytetu Mikołaja Kopernika w Toruniu. Adres: Wydział Politologii i Studiów Międzynarodowych UMK, ul. Batorego 39L, 87-100 Toruń; e-mail: mszulak@uni.torun.pl.

${ }^{1}$ Por. August Cieszkowski, Ojcze nasz, t. 3 (Poznań: Fiszer i Majewski, 1923), 223. 
nie jest działaniem na wskroś ludzkim, odpuszczenie zaś jest działaniem na wskroś boskim. I właśnie w tym obszarze najmocniej spotykają się Bóg i człowiek. W prośbie tej zakłada się również, że inni nas krzywdzą, ale i to, że my sami potrzebujemy przebaczenia ${ }^{2}$.

Lecz prośba ta jest szczególna głównie dlatego, że nasze czasy przepełnione są krzywdami, winami, złem, grzechem, doświadczenie zła zaś głęboko przenika nasze codzienne doświadczenie egzystencjalne. Bez przebaczenia świat taki narażony jest na całkowitą destrukcję: bez przebaczenia ani my, ani nasz świat nie możemy przetrwać. Przebaczenie jest dlatego wielką potrzebą współczesności. Obserwowane dzisiaj przepełnienie złem, czy też jego uwewnętrznienie, nie znaczy oczywiście, że jako ludzie jesteśmy jacyś wyjątkowo źli, przewrotni i winni, i potrzeba nam więcej przebaczenia. Odwrotnie, sytuacja ta nie wynika wcale $\mathrm{z}$ tego, że więcej w tym świecie czynimy zła i wyrządzamy krzywd, lecz raczej z tego, że znacznie lepiej wszystko to diagnozujemy. Mimo podejmowania wielu prób manipulacji w sprawie dobra i zła, ludzkie sumienie bardzo się wyostrzyło w ciągu ostatnich wieków. W trakcie ich upływu bowiem nauczyliśmy się zło rozpoznawać i stąd bardziej niż kiedykolwiek stoimy w jego obliczu. Nauczyliśmy się doświadczać siebie w odniesieniu do dobra i zła, i to doświadczenie stało się doświadczeniem powszechnym. Bardzo często się też przekonujemy, że językiem, jakim możemy mówić o złu, winach i krzywdach, nie jest wcale język logiki, lecz właśnie odmienny od niego język miłosierdzia i przebaczenia, w których oczekuje się nawet pewnych postaw wbrew logice. Możemy powiedzieć w tym kontekście, że współcześnie bardziej możemy (i powinniśmy) przebaczać, gdyż lepiej zrozumieliśmy doświadczenie dobra i zła. Znaleźliśmy się też w sytuacji, w której właśnie przebaczenie staje się uzdrawiającą siłą dla jednostek, społeczeństw i kultur. Przez nie dokonuje się uzdrowienie relacji międzyludzkich, międzykulturowych, które zdominowane zostały przez zło i krzywdę.

Jeśli to wszystko weźmiemy pod uwagę, to łatwo dostrzec, że ważną rolę w aktach przebaczenia odgrywa zawsze poznanie. Jednak ,znajomość dobra i zła" jest tylko jednym z niezbędnych warunków, które mogą kreować akty przebaczenia, i które powinny stać się koniecznością naszej kultury. To jednak, czy takie rozpoznanie będzie służyć dalszemu rozwojowi duchowemu, i czy zaowocuje przebaczeniem, czy też ograniczy się tylko do posiadania wiedzy na temat dobra i zła i rozpoznanej krzywdy, zależy już od

2 Robert Tillman Kendall, Przebaczyć do końca, thum. Piotr Blumczyński (Katowice: Wydawnictwo Credo, 2006), 71. 
nas samych. Obserwując współczesną kulturę, łatwo zauważyć, że za tym powszechnym rozpoznaniem wcale nie idą jednak akty przebaczenia. Mądry aksjologicznie człowiek współczesny zbyt często zatrzymuje się tylko na tym rozpoznaniu, ma wiedzę, potrafi oceniać, lecz powstrzymuje się przed odbudową wzajemnych dobrych relacji: powstrzymuje się przed przebaczeniem. Stąd możemy powiedzieć, że nie wystarczy umiejętność rozróżniania dobra i zła, aby pojawiły się akty przebaczenia. Rozpoznając zło, wiedząc o doznanych krzywdach, człowiek może dopiero stanąć na drodze do przebaczenia. Często jednak tego nie czyni, skutecznie zagradzając przed nim drogę i umacniając potrzebę gniewu, bólu, nienawiści i zemsty.

Kiedy przebaczasz - pisze Edward M. Hallowell - wyrzekasz się gniewu i urazy. Rezygnujesz ze swojego prawa do tych emocji. Wyrzekasz się ich, odwracasz się do nich plecami. Decydujesz, że nie będziesz trwał pod ich rządami. Świadomie i celowo odrzucasz swoje prawo do czegoś, czego prawdopodobnie pragniesz najbardziej na świecie - kary, zemsty, wyrównania rachunków. Taka postawa wymaga niezwykłej odwagi i siły ${ }^{3}$.

Tej odwagi często człowiekowi współczesnemu brakuje.

Dlatego trzeba podkreślić, że tak po stronie przebaczającego, jak też po stronie pokrzywdzonego, doświadczającego zła, upokorzeń, przebaczenie wymaga nie tylko znajomości dobra i zła, lecz również decyzji do działania w pewnym kierunku ${ }^{4}$ Decyzję taką wyznacza „chęć rezygnacji z własnych roszczeń"s. Przebaczenie jest zatem decyzją i działaniem (formą działania), a nie sentymentalnym uczuciem i stanem ducha. Dobro, które się zna, jest w nim siła, która zmusza do działania w pewnym kierunku. Zarówno skrzywdzony, jak i krzywdziciel nie mogą z tego wysiłku rezygnować. Możemy dlatego powiedzieć, że przebaczenie, choć wyrasta z wiedzy na temat dobra i zła, wymaga podjęcia działania i aktywności, w których przebudowuje się rzeczywistość. Czego jednak możemy (i chcemy) oczekiwać od tej aktywności?

3 Edward M. Hallowell, Miej odwage wybaczyć, tłum. Monika Walendowska (Warszawa: Klub dla Ciebie, 2007), 39.

${ }^{4}$ Avis Clendenen, Troy Martin, Uzdrawiajaca moc przebaczenia, tłum. Jerzy Wolak (Kraków: WAM, 2004), 29.

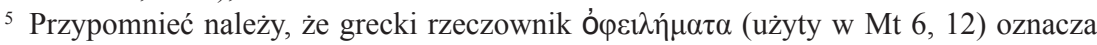
również „dług”, czyli obowiązek pewnego świadczenia. 
Przebaczenie jest działaniem, aktywnością, jaką podejmuje człowiek w pewnej sytuacji. Jest to sytuacja krzywdy, poczucia winy, ale też rezygnacji z odpłacenia tym, co się krzywdzicielowi słusznie należy, rezygnacji z roszczeń zadośćuczynienia i z zemsty. Tak jednak jak od każdego działania i od niego trzeba oczekiwać przekształcenia rzeczywistości, przemiany nas samych, odbudowy relacji międzyludzkich i wreszcie umocnienia świata wartości. To wszystko realizuje się w przebaczeniu. Istotą aktywności przebaczenia jest zatem przemiana, nawrócenie, metanoja, obejmująca tak samo samorozumienie, jak też myślenie, postępowanie i samo istnienie. Jeśli jednak uwzględnimy i podkreślimy ten wymiar przebaczenia, to zadać należy pytanie o to, co właściwie się ,przemienia” w aktach przebaczenia? I - dodatkowo - o jaką przemianę chodzi? O przemianę w jakim kierunku?

Człowiek w swym indywidualnym Ja jest skłonny do częstych przemian. Zmienia się w zależności od świata zewnętrznego, pod wpływem innych ludzi, ale też w zależności od swego nastroju. Jednak przemiana za sprawą przebaczenia nie jest tylko zwykłą zmianą i przebudową całego swego życia. Z jednej strony zostaje w nim zanegowana idea samowystarczalności człowieka, z drugiej zaś ujawnia się poryw człowieka ku wyższej rzeczywistości i możliwość skierowania ku temu, jakim mógłby być. Mimo unurzania człowieka w zło, krzywdę, tkwi w nas możliwość przemiany podstaw ludzkiej egzystencji. Przebaczenie jest aktem właśnie takiej przemiany; w nim człowiek przewyższa siebie samego i jako skończoność wkracza w nieskończoność.

Jednak nie byłoby właściwe podkreślenie tylko tego, że w aktach przebaczenia chodzi wyłącznie o przemianę człowieka. Co prawda doświadczenie takiej przemiany jest $\mathrm{w}$ nich najbardziej widoczne, lecz mówiąc o przemianie za sprawą przebaczenia, należy sięgnąć znaczne głębiej. Przemianie samego człowieka towarzyszy przemiana całego istnienia. W aktach przebaczenia człowiek uczestniczy w stworzeniu nowego świata. To znaczy, że ujawnia się w nich nie tylko nowy człowiek, ale tak samo nowy świat. Moje przebaczenie nie tylko na nowo tworzy człowieka, który dopuścił się zła i krzywdy, lecz tak samo tworzy nowy świat, przemienia dotychczasową postać świata. Można powiedzieć, że w wymiarze ludzkim za sprawą przebaczenia przywraca się człowieka do autentycznego człowieczeństwa, w wymiarze metafizycznym zaś przywraca się rzeczywistość do jej autentycznej formy bycia i neguje fałszywy jej wymiar. 


\section{Krzywda i moralny wymiar przebaczenia - kreacja czlowieka na nowo}

Akty przebaczenia wymagają istnienia ich adresata, czyli kogoś, ku komu je kierujemy, kto pragnie uzyskać przebaczenie, prosi o nie i oczekuje. W przebaczeniu zakłada się zatem, że istnieje podmiot (ktoś), który podejmuje pewne działania (złe i krzywdzące) i się w nich jakoś wyraża ${ }^{6}$. Nie jest to jednak wyrażanie zupełne: sama możliwość uzyskania przebaczenia dosadnie wskazuje, że człowiek podejmujący te „złe działania” jest kimś więcej niż jego czyny. Nie byłoby aktów przebaczenia bez przyjęcia, że związek takiego podmiotu i jego działań można rozdzielić, to znaczy istnieje możliwość swoistego „wycofania” się człowieka z jego własnego (złego) działania. Bez uznania zatem, że człowiek nie wyczerpuje się wcale w tym, co czyni i myśli, lecz ,jest kimś więcej”, przebaczenie nie byłoby możliwe. Takie wycofanie realizuje się nie tylko wtedy, gdy zrozumiał on czynione przez siebie zło i krzywdę wyrządzoną innemu, ale również i wtedy, gdy doświadcza on tego, że wcale się z nimi nie utożsamia. Jednocześnie przebaczenie nie jest również możliwe bez udziału tego innego, który doznał krzywdy. Jego (skrzywdzonego) działanie nie uruchamia zatem całego procesu przebaczenia, lecz niejako „dopełnia”, zezwalając i utwierdzając jego możliwość, a nawet konieczność. Możemy powiedzieć, że owo „wycofanie” jest możliwe, gdy chce tego krzywdziciel (przepraszając) i pokrzywdzony (przebaczając). Dlatego należy stwierdzić, że przebaczenie realizuje się tylko przy pomocy kogoś innego i nie jest możliwe ani w postaci „samoprzebaczenia", rozgrzeszenia samego siebie, ani też bez wyraźnego wycofania z działań czynionego zła i krzywd. Przebaczenie ma charakter naprawiania zła i krzywdy z inicjatywy krzywdziciela i przy udziale pokrzywdzonego. I po obu stronach nie jest obowiązkowe: krzywdziciel nie musi o nie prosić, a pokrzywdzony nie musi jego udzielać. Coś nadzwyczajnego dzieje się jednak, gdy (po obu stronach) aktywność taka się pojawia.

Już tu łatwo dostrzec, że problematyka związana z poczuciem winy i z przebaczeniem jest problematyką złożoną. Najczęściej jednak dominującym wymiarem, w jakim się pojawia, jest wymiar moralny, który zostaje połączony z wymiarem religijnym. Obydwa te wymiary wydają się wyznaczać współczesny status quaestionis dyskusji o przebaczeniu. Przebaczenie ukazuje się nam zawsze jako akt zabarwiony aksjologicznie, który wyłania

${ }^{6}$ Robert Spaemann, Szczęście a życzliwość. Eseje o etyce, tłum. Jarosław Merecki (Lublin: Redakcja Wydawnictw KUL, 1997), 252. 
się z ludzkiej wrażliwości moralnej. I im bogatsza jest ta wrażliwość, tym łatwiej o przebaczenie. Trzeba też podkreślić, że zajmując się przebaczeniem w tym kontekście, koncentrujemy się na ,przebaczeniu komuś”. Jeśli do tego wymiaru aksjologicznego dołączony zostaje wymiar religijny, to otrzymuje ono dodatkowo charakter aktywistyczny, w którym przyjmuje się, że nie wystarczy poczekać, aby przeminęło zło, gniew, ból, nienawiść, zemsta, lecz należy podjąć ,jakąś" aktywność, aby wszystko to przezwyciężyć. Aktywnością tą jest właśnie przebaczenie ${ }^{7}$. Jego rezultatem zaś nie jest tylko zgoda, zaprzestanie waśni, ale coś znacznie więcej. W wymiarze aksjologicznym od aktów przebaczenia zależy przywrócenie człowieka, który jest winny i odpowiedzialny za zło, do jego pełnego istnienia. Jeśli pojawia się więc prośba o przebaczenie, która rozpoczyna ten proces, i samo przebaczenie, w którym zostaje on spełniony, to zło, czynione przez człowieka, zmienia radykalnie swe oblicze: staje się ono tylko czymś przygodnym, zdarzającym się, a nie na trwale przylegającym do człowieka. I właśnie w akcie przebaczenia człowiek otrzymuje na nowo możliwość utwierdzenia się w swoim istnieniu. Wraz z nim pojawia się możliwość rozpoczęcia swego życia od podstaw i jest niejako rozpoczęciem ludzkiego bytowania na nowo. Akt przebaczenia przywraca człowieka do jego bycia.

Jak zatem łatwo dostrzec, równoległym (obok rozpoznania dobra i zła) warunkiem aktu przebaczenia, ujmowanego w jego moralnym wymiarze, jest konieczność poczucia winy/skrucha po stronie winowajcy, połączona z koniecznością kary/pokuty. Jeśli jednak uwzględnimy tę tezę, to łatwo dostrzec, że w tym wymiarze przebaczenia odsłaniają się dwa istotne problemy. Pierwszym jest pytanie o to, czy może pojawić się samo przebaczenie, jeśli nie towarzyszy jemu akt skruchy i prośba o nie? Drugim jest pytanie o to, czy istnieje możliwość odmowy przebaczenia, jeśli taka prośba już się pojawi?

\section{Przebaczenie bez skruchy}

Odpowiadając na pierwsze pytanie, należy stwierdzić, że w wymiarze moralnym warunkiem przebaczenia jest prośba o nie, akt skruchy i naprawienie wyrządzonej krzywdy. Już Platon w Gorgiaszu wskazywał, że ten, który uczynił zło, powinien pragnąć kary. „Celem każdej kary - mówi Platon

7 Giuseppe Soveringo, Poczucie winy, thum. Stanisław Obirek, Stanisław Pyszka (Kraków: M, 1993), 31. 
słowami Sokratesa - jeśli jest sprawiedliwa, jest uczynienie lepszym tego, kto ją znosi, a zatem przyniesienie mu korzyści albo stanie się przestroga dla innych, by ci widząc takie cierpienia z obawy stawali się lepsi"'. To jednak nie wystarczy do przywrócenia porządku i człowieczeństwa. Potrzeba jeszcze, aby w ten proces oczyszczania włączył się pokrzywdzony wraz z przebaczeniem. Cały ten proces rozpoczyna się jednak od winnego jako tego, który uczynił zło. Podjęta w skrusze decyzja przemiany („Chcę się zmienić”) jest zawsze dopiero początkiem przebaczenia („Przebaczam, abyś się zmienił”). Dlatego słusznie podkreśla Sergej Prokofieff: „Wraz ze skruchą rozpoczyna się wyrównanie przeszłości, wraz z przebaczeniem zaczyna się stwarzanie przyszłości" . Simone Weil, analizując w tym sensie związek między karą i przebaczeniem, stwierdza: „Człowiek obrażony przebacza dopiero wtedy, gdy ten, co go obraził, został ukarany i upokorzony czy to zgodziwszy się sam poddać karze (jak to często bywało w średniowieczu), czy to, gdy sam zmuszony do niej, powiedział w końcu, jak chłostani w Rzymie niewolnicy: przebacz mi, dość wycierpiałem" ${ }^{10}$. Zdanie to może wydać się nawet szokujące, a próba łączenia przebaczenia z koniecznością skruchy i poniesienia kary za przewinienia jest jakimś zaburzeniem tego aktu. Trzeba jednak zaraz zauważyć, o co w tym moralnym przebaczeniu naprawdę chodzi. Ma ono przecież przywrócić winnego do człowieczeństwa, odzyskać jego wymiar ludzki i przemienić. I nie może się to odbyć bez jego aktywnego udziału, który można nazwać „oddzieleniem jego/człowieka od czynu”. Podobnie jak pierwszy warunek (poznanie dobra i zła), i to doświadczenie ludzkie (poczucie winy) jest swoistym doświadczeniem siebie w odniesieniu do rozpoznanego dobra i zła. „Zasadniczo jest to uczucie pożyteczne i normalne, umożliwiające naprawę błędu czy wyrównanie wyrządzonej krzywdy. Ale jeśli trwa ono, nie prowadząc do poprawy, albo jeśli zatrzymuje się na oskarżaniu i pogardzie dla samego siebie, zamiast prowadzić do otwarcia się na poprawę, przybiera postać patologiczną" "11. To znaczy, że nie może być prawdziwego (pełnego) przebaczenia bez jasnego ujawnienia prawdy o tym, co się wydarzyło. W poczuciu winy człowiek doświadcza siebie jako kogoś,

8 Platon, Gorgiasz, thum. Paweł Siwek (Warszawa: PWN, 1991), 128.

9 Sergej O. Prokofieff, Duchowe znaczenie przebaczenia, tłum. Michał Waśniewski (Gdynia: Genesis, 2006), 78.

${ }^{10}$ Simone Weil, Świadomość nadprzyrodzona. Wybór myśli, thum. Aleksandra Olędzka-Frybesowa (Warszawa: Instytut Wydawniczy PAX, 1986), 71.

11 Soveringo, Poczucie, 34. 
kto jest obarczony złem, choć oczywiście do przebaczenia nie prowadzi neurotyczne poczucie winy ${ }^{12}$.

Tak zatem w wymiarze moralnym, w którym chodzi o przemianę człowieka i odzyskanie przez niego człowieczeństwa, poczucie winy i prośba o przebaczenie stanowią nieodłączny wymiar tego aktu. Stanowią one bowiem niezbędny element uświadomienia sobie sytuacji, w jakiej znalazł się czyniący zło i wyrządzający krzywdę. Bez uświadomienia sobie owej rzeczywistej sytuacji, w jakiej się znalazł człowiek, nie jest możliwa przemiana i odzyskanie własnego człowieczeństwa. Dlatego poczucie winy stanowi prawdziwy przewrót $\mathrm{w}$ doświadczeniu zła ${ }^{13}$. Ale tak samo ono dopiero umożliwia i rozpoczyna akt przebaczenia. Bez ujednostkowienia winy, jej uświadomienia i skruchy przebaczenie w sensie moralnym nie spełnia swej funkcji przemiany i odnowy człowieka.

\section{Odmowa przebaczenia}

Warunkiem przebaczenia w sensie moralnym i aksjologicznym jest egzystencjalny wstrząs spowodowany świadomością wyrządzonej krzywdy i winy. Człowiek winny całą swą egzystencją musi stawić czoła skutkom swego przewinienia. Nie trzeba dodawać, że doświadczenie bycia winnym jest stałą częścią doświadczenia ludzkiego. Można powiedzieć, że poczucie winy dotyczy każdego człowieka, choć jest przeżywane w różnym stopniu. Za każdym razem mówi taki człowiek: „Przebacz, co prawda ja to uczyniłem, lecz ja taki nie jestem. Jestem/chcę być inny". Warunkiem możliwości odnowy człowieka jest jednak uzyskanie przebaczenia. Od strony pokrzywdzonego jest to jedna $\mathrm{z}$ form reakcji na doznane rzeczywiste zło, które dotyka nas w życiu, w różnych jego obszarach, w sferze indywidualnej, społecznej, politycznej, religijnej i intelektualnej. Przebaczenie jest jednak tylko możliwą, lecz niekonieczną reakcją na ogarniającą nas otchłań zła. „Akt przebaczenia - stwierdza Marian Grabowski - czerpie swój sens $z$ dramatu krzywdy i win"14. Jednak akt ten jest działaniem indywidualnym,

12 Karen Horney, Neurotyczna osobowość naszych czasów, thum. Helena Grzegołowska (Warszawa: PWN, 1982), 154. Neurotyczne poczucie winy nigdy nie prowadzi do przebaczenia, gdyż u jego podstaw tkwi paraliżujący lęk.

${ }^{13}$ Por. Paul Ricoeur, Symbolika zła, tłum. Stanisław Cichowicz, Maryna Ochab (Warszawa: Instytut Wydawniczy PAX, 1986), 98.

${ }_{14}$ Marian Grabowski, Krajobraz winy. Próba analizy fenomenologicznej (Torun: Wydawnictwo UMK, 2001), 77. 
który człowiek może realizować lub nie. Nieskorzystanie z tej możliwości wydaje się tak samo miarą człowieka, jak odczucie win i prośba o ich wybaczenie. Oznacza to, że problem reakcji pokrzywdzonego na skruchę i prośbę o przebaczenie może przybrać dwa pytania. Pierwszym jest pytanie o to, co dzieje się z człowiekiem z poczuciem winy, który prosi o przebaczenie i je otrzyma. Drugim zaś pytanie o to, co dzieje się z człowiekiem, który doznał zła i krzywdy, słyszy prośbę o przebaczenie i jego nie udziela.

Jeśli chodzi o pierwsze pytanie, to odpowiedź nasuwa się sama: rezultatem udzielonego przebaczenia jest przemiana człowieka, który poczuwa się do winy, przeprasza i obiecuje poprawę. Staje się on nowym człowiekiem. Drugie pytanie wymaga głębszej analizy. Ten moralny wymiar przebaczenia, gdy w stronę pokrzywdzonego kierowana jest prośba o przebaczenie, ten jednak jej nie spełnia, wielokrotnie był poddawany analizom w filozofii i literaturze w każdej epoce, począwszy od Sofoklesa, a skończywszy choćby na wielkich dziełach Dostojewskiego (np. Skrzywdzeni i poniżeni, Zbrodnia i kara). Niektórzy bohaterowie Dostojewskiego nie przebaczają, choć prośba o przebaczenie dotyka ich bardzo mocno. Przywołajmy jednak przykład, w którym - z jednej strony - podkreślone jest uświadomienie wyrządzonego zła i krzywdy (krzywdzący zrozumiał czynione przez siebie zło), z drugiej zdecydowana i szczera prośba o przebaczenie (chce prosić o przebaczenie i to czyni), lecz wszystko to spotyka się ze zdecydowaną odmową jego udzielenia. Jest to przykład wydarzeń opisanych przez Szymona Wiesenthala.

W roku 1969 Szymon Wiesenthal opublikował niezwykłą historię, która stała się na dziesięciolecia przedmiotem licznych dyskusji. Nosi ona tytuł Die Sonnenblume. Von Schuld und Vergebung ${ }^{15}$ (Stonecznik. O winie i przebaczeniu). Tę niezwykłą historię trudno nazwać opowieścia, jest to raczej podwójna spowiedź: samego Wiesenthala, który opowiada całe wydarzenie, i młodego esesmana, który w poczuciu swoich win prosi o przebaczenie. Opisane w niej wydarzenia rozgrywają się w czasie II wojny światowej. Wiesenthal znajdował się wtedy w niemieckim obozie nazistowskim pod Lwowem. Pewnego razu wraz z grupą więźniów został przyprowadzony do prac w szpitalu wojskowym. Podczas tych prac podeszła do niego pielęgniarka, zapytała czy jest Żydem i kazała iść ze sobą. Przyprowadziła go do ciężko chorego, umierającego młodego człowieka, owiniętego w bandaże.

15 Simon Wiesenthal, Die Sonnenblume. Von Schuld und Vergebung (Paris: Opera Mundi, 1969). Tłumaczenie polskie ukazało się w roku 2000. Por. Szymon Wiesenthal, Słonecznik. Opowieść i komentarze, thum. Magdalena Kurkowska, Katarzyna Sendecka (Warszawa: Państwowy Instytut Wydawniczy, 2000). 
Ten jeszcze raz upewnił się, że przyszedł do niego Żyd, i zaczął opowiadać swoje życie. Wiesenthal słuchał spowiedzi młodego esesmana, który opowiadał swe losy i szczególnie akcentował własne potworne zbrodnie popełnione na Żydach. W tej spowiedzi łatwo było dostrzec wielką moralną udrękę i wyrzuty sumienia człowieka, mordercy, który żałuje swych czynów przed nadchodzącą śmiercią. Pod koniec rozmowy mówi: „Wiem, że to, co Panu opowiedziałem, jest straszne. W długie noce, czekając na śmierć, odczuwałem ciągle potrzebę, by porozmawiać o tym z Żydem... i poprosić go o przebaczenie. Nie wiedziałem tylko, czy w ogóle jacyś Żydzi jeszcze żyją... Wiem, że wymagam od pana niemal za dużo. Ale bez odpowiedzi nie mogę umrzeć" ${ }^{16}$. Po tych słowach zapadła cisza, Wiesenthal opuścił pokój w milczeniu. Umierający esesman, morderca Żydów, nie otrzymał przebaczenia.

Ta poruszająca scena dotyka jednej z najważniejszych kwestii związanych z moralnym wymiarem przebaczenia. Czy można odmówić przebaczenia? Jeśli tak, to w jakiej sytuacji? I czy można odmówić przebaczenia umierającemu? W tradycji chrześcijańskiej przyzwyczajeni jesteśmy, że w tej „ostatecznej decyzji” przebaczenia nie można odmówić. Takie przeświadczenie wynika z uznania, że gdy umierający prosi o przebaczenie, to w prośbie tej nie chodzi już o jego przemianę i poprawę, lecz o swoiste „otwarcie drogi” do życia wiecznego. Chrześcijanin wie, że nie może tej drogi zamykać. Dlatego umierający esesman, po wyznaniu zbrodni i żalu za nie, zasłużył na przebaczenie. Więcej nawet: w sensie teologicznym on nawet takie przebaczenie otrzymał przez wzbudzenie szczerego żalu za uczynione zło. Właśnie w tej prośbie dostrzec można, jak moralny wymiar przebaczenia styka się z przebaczeniem o jakimś innym charakterze, z przebaczeniem metafizycznym. Sytuacja zmienia się radykalnie, jeśli odrzuci się możliwość życia wiecznego, a samo przebaczenie ograniczone zostaje do wymiaru moralnego i przemiany człowieka. Zło popełnione przeciw człowiekowi zostaje niejako anulowane wraz ze śmiercią winowajcy. Dlatego w tej sytuacji pytanie o to, czy udzielić przebaczenia umierającemu, jeśli o to prosi, staje się mniej istotne, a odpowiedź na nie przestaje mieć znaczenie. Słowem: jeśli nie odkryje się innego wymiaru przebaczenia niż moralne, jeśli nie dostrzeże się jego znaczenia dla otwarcia drogi do życia wiecznego, udzielenie jego umierającemu staje się zupełnie nieistotne.

Jeśli powrócimy do opowiadania Wiesenthala, to pojawia się tu jeszcze jeden element odnoszący się do odmowy przebaczenia. Jest to pytanie o to,

16 Tamże, 56. 
czy mamy prawo udzielać przebaczenia za innych? Z jednej strony łatwo dostrzec, że im łatwiej przebaczamy, tym słabsze, przemijające i przypadkowe staje się zło gnębiące człowieka. „Widziałem w swoim życiu wiele dziwów i osobliwości - pisze Władimir Sołowjow - lecz dwóch rzeczy nigdy nie spotkałem w naturze: człowieka, który by z pewnością był absolutnie dobry, i człowieka, który by z pewnością był absolutnie zły"17. Człowiek, który prosi o przebaczenie, i ten, który przebacza, dokonują wspólnej anihilacji zła, przekreślając jego wpływ na relacje międzyludzkie i więzi społeczne. Jednak ta prośba o przebaczenie jest czymś znacznie szerszym niż tylko skierowaniem nas do świata moralności. Wraz z nią dokonuje się wyraźnego przekierowania świata i życia człowieka w stronę ducha i duchowości. Przy tym skoncentrowanie przebaczania na sferze moralnej oznacza często, że skupiamy się na relacji „Ja i moja wina”, stąd człowiek może wybaczyć tylko za siebie, nie może wybaczać za innych. Oczywiście, w akt przebaczenia włączone jest indywidualne uczucie ulgi i uwolnienia. „Zapomnienie wyrządzonego człowiekowi zła i ciągłe pamiętanie o konieczności wnoszenia w świat miłości i dobra jako jedynego środka, który może przezwyciężyć w świecie skutki zła, to dwa podstawowe warunki przebaczenia" ${ }^{18}$. W wymiarze moralnym przebaczać można tylko za siebie, a nie za innych. Nikt nie może przebaczać za drugiego człowieka, nie można bowiem usuwać cudzych cierpień. Co oczywiście nie oznacza, że nie mamy tu możliwości do działania. Można (i trzeba) modlić się o takie przebaczenie dla innych.

\section{Moralne przebaczenie dzisiaj}

Jakie $\mathrm{z}$ tych analiz wynikają podstawy tego, że przebaczenie nie jest częstym aktem podejmowanym przez współczesnego człowieka? Człowiek współczesny często nie potrafi już ujmować dobra i zła w ,jego istocie”, lecz ocenia je w zależności od tego, czemu służy i w jakich okolicznościach. Na miejscu samego Dobra stawia się coś, co jest dobre, lecz może się stać złe; za bezwzględne uznaje się to, co względne ${ }^{19}$. W wymiarze moralnym przebaczanie funkcjonuje w określonych okolicznościach i w pewnych okolicznościach może być zawieszone, jak to dostrzec można w historii Wiesenthala.

17 Władimir Sołowjow, Uzasadnienie dobra. Filozofia moralna, thum. Paweł Rojek, Marek Kita, Katarzyna Janowska, Leszek Augustyn (Kraków: Wydawnictwo UJ, 2005), 8.

18 Prokofieff, Duchowe, 78.

19 Sołowjow, Uzasadnienie, 20. 
Nie jest trudno te okoliczności zdiagnozować. Jeśli doświadczamy niepowodzeń we wzajemnej łączności, jeśli nie potrafi się zapobiec zerwaniu bliskiego kontaktu z drugim człowiekiem, jeśli drugi człowiek jawi się zawsze jako byt, który jest konkurentem i zagrożeniem, jeśli - wreszcie - nie odczuwamy już wspólnoty naszych losów, to wszędzie tam wiedza na temat dobra i zła nie doprowadzi do aktów przebaczenia. Wraz z zerwaniem tej łączności musi pojawić się odmowa i uniemożliwienie przebaczenia. Wydaje się dzisiaj, że jest w nas i kulturze współczesnej coś, co sprzeciwia się wzajemnej łączności. Możemy powiedzieć, że im mniej łączności z innymi, im mniej komunikacji, im dłuższa droga do drugiego człowieka, tym mniejsze szanse na akty przebaczenia. Akty przebaczenia w tym wymiarze wymagają bowiem czegoś, co przed laty Emmanuel Mounier nazwał ruchem ku drugiemu człowiekowi. Z kolei nadmierne skupianie się na sobie akty te skutecznie uniemożliwiają. Nie można bowiem przebaczać, jeśli nie dostrzega się tego, komu się przebacza, ani też tego, że winny zdany jest na przebaczenie i jego oczekuje.

\section{Krzywda, grzech i metafizyczny wymiar przebaczenia - kreacja nowej rzeczywistości}

Powtórzyć trzeba, że najczęściej przebaczenie odnosimy do sfery moralnej i jego wymiaru aksjologicznego. Przebaczenie jest tu wyraźnym znakiem, że zło i krzywda nie są ani konstruktywne dla człowieka, ani też nie należy do nich ostatnie słowo. W tym sensie przebaczenie wkomponowane jest w pewien program etyczny, w którym zawsze znajduje się podmiot przebaczenia, któremu się przebacza za coś i pod pewnymi warunkami. Jest to „przebaczenie komuś”, ale jednocześnie jest to jakaś próba kreacji człowieka „na nowo”, jego przemiany i powrotu na właściwą drogę. W przebaczeniu takim zakryte (choć nie wymazane $)^{20}$ zostają winy człowieka i pojawia się on na nowo, jako nowy człowiek. Tego bowiem, co się wydarzyło, nie można usunać, w sensie przywrócenia takiego stanu, jak gdyby nic się nie stało. Akty przebaczenia nie mogą przywrócić tego stanu pierwotnego i dokonać swoistej restytucji. Często powstrzymywanie się przed przebaczeniem wynika właśnie z przeświadczenia, że nawet w nim nie można przekreślić wydarzenia i powrócić do pierwotnego stanu. Jeśli zaś tego nie można, to -

${ }^{20}$ Por. Avishai Margalit, „Przebaczanie i zapominanie”, tłum. Zofia Rosińska, Kronos 4 (2009): 160. 
sądzi się - przebaczeniu odbiera się możliwość twórczego oddziaływania na rzeczywistość. Należy jednak podkreślić błędny kierunek tego rozumowania. Przebaczenie rzeczywiście nie jest przywróceniem nieskażonej rzeczywistości sprzed krzywdy i złego czynu. Nie przywraca ono rajskiego świata, „stanu niewinności”, lecz przemienia człowieka, tworzy nowy stan rzeczy. A przede wszystkim tworzy nowego człowieka: to on, człowiek, staje się na nowo. W tym aksjologicznym wymiarze nie może też być przebaczenia bez skruchy winowajcy, przeprosin i zakrycia win. Jeśli tego wszystkiego nie będzie, to cel kreacji nowego człowieka nie zostanie w pełni osiagnięty. $\mathrm{Z}$ jednej zatem strony doznający krzywd nie trzyma się w nim własnego prawa „odpłaty za zło”, lecz tworzy inne prawo, w którym zło nie znajduje oporu i tym samym nie kreuje już nowego zła. Z drugiej strony jednak, aby to nowe prawo naprawdę zaczęło działać i winny rzeczywiście stał się innym człowiekiem, potrzebna jest również aktywność „po jego stronie”. To dzięki przebaczeniu winny przekonuje się, że krzywdząc i wyrządzając zło, zawsze też krzywdzi samego siebie. Nie można bowiem czynić zła i krzywdzić jakiejkolwiek istoty, nie wyrządzając jednocześnie zła i krzywdy samemu sobie. Przebaczenie jest wielką pomocą udzielaną człowiekowi w powrocie do ludzkiego bytu, odnowy człowieczeństwa i do życia na nowo. Przemiana, o jaką tu chodzi, jest przemianą człowieka.

Jednak obok tego naturalnego wymiaru łączenia przebaczenia $\mathrm{z}$ naszą wrażliwością moralną i winą wskazać należy jeszcze jeden jego wymiar, który każe wywodzić przebaczenie z naszej wrażliwości metafizycznej, metafizycznego usytuowania człowieka i grzechu. Jest to także przebaczenie skierowane ku komuś, ale - wkraczające w głąb samego istnienia, samego bytu - prowadzi ono do przemiany całego istnienia. Można powiedzieć, że w nim i dzięki niemu odkrywana jest głębia bytu i zmierza się ku przemianie oraz poprawie ,jakości świata jako całości”. Taka pogłębiona wrażliwość metafizyczna oznacza, że doznaje się, iż wyrządzone zło i krzywdy odnoszą się nie tylko do konkretnego człowieka, wobec którego czujemy się winni lub pokrzywdzeni i któremu możemy przebaczyć, lecz odnoszą się do całego istnienia. Każdy człowiek jest bowiem służebną cząstką tego Istnienia i jego człowieczeństwo jest doznawane zawsze w odniesieniu do niego. Kto dostrzega ten wymiar, dla tego akt przebaczenia przekracza dobro i zło oraz wymiar aksjologiczny. Wyrządzone zło i krzywda nie są wcale tylko negacją i zagubieniem człowieka, nie dotyczą tylko tej konkretnej sytuacji i tego konkretnego człowieka, ale są też zawsze gwałtem zadanym bytowi. Słowem: nie są tylko winą człowieka, lecz grzechem, nie są tylko wielkością moralną, lecz są wielkością metafizyczną i religijną. 
Można powiedzieć, że w sensie moralnym przebaczyć można winy człowieka, w sensie metafizycznym zaś przebaczenie odnosi się do grzechu, który sytuuje człowieka jako przeciwnika istnienia i Boga. Grzech jako taki jest odpadnięciem od Dobra, zerwaniem więzi i odwróceniem się od całego istnienia. Bo też i człowiek nigdy nie stoi przed światem, lecz zawsze jest bytem w świecie, i nie jest w stanie uchylić się od tej sytuacji. W tym sensie przebaczenie jest chęcią (i koniecznością) ofiarowania nie tylko drugiemu człowiekowi, ale również kulturze, światu, istnieniu tyle samo miłości i dobra, ile wszyscy oni utracili wraz z uczynionym/doznanym złem. Przebaczenie umożliwia powrót do tej pierwotnej więzi. Poetycko pisze o tym Simone Weil: „Wszelkie zrodzone na tym świecie zło przenosi się od człowieka do człowieka (...), aż do momentu, gdy natrafi na istotę doskonale czystą która je przyjmie na siebie w całości i w ten sposób zniszczy”"21. Takie „przyjęcie na siebie" zła bez uwarunkowań prowadzi do przemiany całego istnienia.

W tym sensie przebaczenie nie tylko przekracza moralność, ale dotyczy samego istnienia, ma sens metafizyczny i nie musi być wiązane z oczekiwaniem przeprosin, poczuciem winy i skruchą winnego. Wszystko to staje się nieistotne, gdyż wynika ono ze swoistej metafizycznej konstytucji człowieka. Można powiedzieć, że pokrzywdzony, doznający zła i upokorzeń, takie bezwarunkowe przebaczenie daruje (oferuje) całemu istnieniu, i czyni to właśnie bezwarunkowo, za darmo, nie oczekując przeprosin, skruchy i żalu. Ma ono też do wypełnienia zadanie innej przemiany. Chodzi w nim o to, aby nie tylko „przywrócić” istnieniu tyle dobra i miłości, ile zostało zeń usunięte na skutek złego czynu i krzywdy, ale też aby umocnić człowieka w tym, że nie jest wcale niszczycielem istnienia, lecz aktywnie w nim uczestniczy i ponosi za nie odpowiedzialność. Takie przebaczenie jest przywróceniem fundamentalnego zaufania, harmonii Istnienia i głębokiej relacji z Bogiem. I to od ,przebaczam” zależy los istnienia, los świata i nowa perspektywa sensu. To o takiej przemianie pisze Paul Tillich: „przemienienie jednej choćby tylko formy bytu w jednym tylko miejscu wszechświata jest nieskończenie ważne dla wszechświata w całości"22. I jak aksjologiczny wymiar przebaczenia jest troską o człowieka i możliwość przywrócenia go na nowo światu, tak w wymiarze metafizycznym trzeba by mówić o jakiejś trosce o samo Istnienie i możliwość jego przemiany, a nawet o odpowiedzialności człowieka za wszelki byt. Udzielający takiego przebaczenia może (i powinien)

${ }^{21}$ Weil, Świadomość, 72.

${ }^{22}$ Paul Tillich, Rzeczywistość Chrystusa. Nowy byt, thum. Jan Adrian Lata (Oleśnica: Oficyna Wydawnicza „Signum”, 1996), 36. 
to uczynić, gdyż jest on odpowiedzialny nie tylko za (drugiego) człowieka, ale również za całe istnienie. Łatwiej ten nowy/inny wymiar przebaczenia zrozumieć, gdy przywołamy biblijną scenę bratobójstwa Abla. Bóg zwraca się w niej do Kaina z pytaniem: „Gdzie jest twój brat Abel?” (Rdz 4, 9). I nie chodzi w tym pytaniu o zło uczynione przez Kaina ani o możliwość przebaczenia w wymiarze aksjologicznym, lecz o odpowiedzialność za brata. Bóg może zadać to pytanie, gdyż uznaje, że Kain był odpowiedzialny za brata. Kain jednak nie chce przyjąć na siebie tej odpowiedzialności i mówi „Nie wiem. Czyż jestem stróżem mego brata" ( $\operatorname{Rdz} 4,9)$. Możemy stąd wnosić, że człowiek jest odpowiedzialny za całe istnienie i właśnie na tej odpowiedzialności spoczywa też metafizyczne przebaczenie. Odnosi się ono dlatego do całej rzeczywistości: związane jest z odpowiedzialnością za kogoś (coś) przed kimś i wyrasta $\mathrm{z}$ troski o całe istnienie. Taką troskę przejawia człowiek, który bezwarunkowo przebacza, który bezwarunkowo oferuje całemu istnieniu powrót do pierwotnego stanu niewinności.

Można zatem powiedzieć, że metafizyczny wymiar przebaczenia przekracza znajomość dobra i zła, i wyrasta z troski i odpowiedzialności za całe istnienie. Odpowiedzialność, jaką ponosi człowiek, nie jest bowiem tylko odpowiedzialnością ,za drugiego człowieka”. Jest ona tak samo odpowiedzialnością za wszelkie istnienie. Odkrycie jednak tej powszechnej odpowiedzialności wymaga najpierw ćwiczenia się w dobru i złu i w moralnym wymiarze przebaczenia. Skąd jednak się bierze ta nadzwyczajna postać przebaczenia metafizycznego i czy człowiek rzeczywiście jest do niej zdolny? Czy rzeczywiście my ludzie potrafimy przebaczać bezwarunkowo? Czy jesteśmy do tego zdolni, aby nie oczekiwać wcale przeprosin i poczucia winy, a jednak przebaczać? Czy rzeczywiście w imię naszej odpowiedzialności za wszelkie istnienie mamy prawo i obowiązek przebaczać bezwarunkowo?

\section{Bóg przebaczający bezwarunkowo}

Bezsprzecznie takiego bezwarunkowego, metafizycznego przebaczenia można oczekiwać od Boga. Jeśli człowiek popełnił grzech, naruszył relację z Bogiem, odwrócił się od całego istnienia, utracił więź i ontologiczne podłoże bytu, to tylko Bóg może swą łaską (jak o tym wiedział już św. Augustyn) przywrócić ten pierwotny stan. Pisze też św. Paweł do Rzymian: „Gdzie zaś grzech się rozmnożył, tam łaska bardziej obfitowała” (Rz 5, 20). I gdyby Bóg nie uczynił tego bezwarunkowo, nie czekając na przeprosiny 
i skruchę, to stan ten nigdy by się nie skończył. Bóg przebacza człowiekowi „za darmo" i bez warunków wstępnych.

Jednak Biblia przepełniona jest również tekstami, które sugerują „warunkowy", aksjologiczny wymiar Bożego przebaczenia, gdy Bóg przebacza winę i grzech człowieka pod jakimiś warunkami. Czytamy na przykład w Księdze Syracha: „Jakże wielkie jest miłosierdzie Pana i przebaczenie dla tych, którzy się do Niego nawracają" (Syr 17, 29). Również umierający na krzyżu Jezus wypowiada słowa, które mogą stanowić podstawę do dyskusji o aksjologicznym i jednak warunkowym wymiarze Bożego przebaczenia. Brzmią one: „Ojcze, przebacz im, bo nie wiedza, co czynią” (Łk 23, 34). Powiązanie aktu przebaczenia z niewiedzą na temat tego, którego krzyżują lub (ogólnie) na temat dobra i zła, wydaje się tu oczywiste. Jeśli oni „nie wiedzą", kim jest ten, kogo krzyżuja, to właśnie ta niewiedza umożliwia przebaczenie, staje się jego uzasadnieniem. Łatwo też dostrzec, że w takim wyjaśnieniu mamy do czynienia z przebaczeniem warunkowym, uzależnionym co prawda nie od poczucia winy i skruchy, lecz od „niewiedzy”. Złośliwi mogliby powiedzieć: nie sztuka przebaczać tym, którzy nie wiedzą co czynią, sztuką jest przebaczyć tym, którzy taką wiedzę mają, a jednak postępują źle. W obu tych przykładach przebaczenie wydaje się mieć aksjologiczny wymiar i dotyczyć naszych win: u Syracha jego warunkiem jest nawrócenie, w modlitwie Jezusa nieświadomość czynu. Ale też w obu przypadkach chodzi o przemianę i odrodzenie człowieka: w Księdze Syracha jest to nawrócenie człowieka, w słowach Jezusa na krzyżu jest to troska o tych ludzi źle czyniących. Obydwa obrazy mogą jednak sugerować, że „Boże przebaczenie" jest również uzależnione od spełnienia przez winnego jakichś warunków początkowych. I jeśli tych warunków nie będzie, to i nie będzie przebaczenia. Podkreślić jednak należy, że scena z ukrzyżowania (i wypowiedziane tam słowa w kontekście przebaczenia) jest wydarzeniem szczególnym. Jezus w niej nie przebacza, lecz prosi Ojca o przebaczenie, szukając okoliczności łagodzących, wstawia się za nich. Prosi i chce przekonać Ojca, że takie przebaczenie tym ludziom krzyżującym się należy. Taką okolicznością jest niewiedza o tym, kogo krzyżują.

Jednak łatwo też dostrzec $\mathrm{w}$ wielu religiach, że Bóg, zamiast potępić człowieka za grzech, podnosi go z upadku i czyni to bez warunków wstępnych. Nie trzeba do tego „przeprosin”, wystarczy zaś to, że człowiek nie ukrywa swej winy ${ }^{23}$. I wydaje się, że do takiego przebaczenia jest zdolny

${ }^{23}$ „Grzech mój wyznałem Tobie / i nie ukryłem mej winy. Rzekłem: «Wyznaję nieprawość moją wobec Jahwe», / a Tyś darował winę mego grzechu” (Ps 32, 5). 
tylko Bóg, gdyż - jak pisze Simone Weil - ,zło zapadnie się w nicość tylko przy zetknięciu się z Bogiem"24. Jednocześnie On jest tym, który nie chce potępiać i niszczyć, lecz „szukać i zbawić to, co zginęło” (Łk 19, 10), i w takim bezwarunkowym przebaczeniu na nowo stwarza świat. Tam bowiem, gdy u człowieka przebaczenie łączy się ze sprawiedliwością, u Boga pojawia się ono w parze z miłosierdziem. Pisze Paul Ricoeur: „Przebaczenie jest jakby zapomnieniem albo odstapieniem gniewu świętości; niekiedy przybiera obrazową formę «Boskiej skruchy», jak gdyby Bóg odmienił obraną drogę, odmienił swoje zamiary wobec człowieka" ${ }^{25}$. I czyni to, nie czekając na przeprosiny i skruchę: zamiast potępić człowieka, Bóg podnosi go i bezwarunkowo przebacza.

\section{Czlowiek przebaczający bezwarunkowo}

Każde przebaczanie jest naśladowaniem Boga. Dlatego zachętę do bycia miłosiernym i my otrzymujemy w słowach: „bądźcie miłosierni, jak Ojciec wasz jest miłosierny" (Łk 6, 36). A to znaczy, że i my mamy szanse przebaczać bezwarunkowo i przemieniać całe istnienie, stwarzać je na nowo. W naszym ludzkim przebaczeniu, uwarunkowanym oczekiwaniem przeproszenia, skruchy i zadośćuczynienia, ujawnia się bowiem nie tylko natura człowieka, ale również sam Bóg. „Człowiek - pisze Edyta Stein - jest powołany na wybawiciela całego stworzenia i może to uczynić, jeżeli sam jest odkupiony"26.

Możliwość takiego bezwarunkowego przebaczenia wynika z pewnością $\mathrm{z}$ tego naśladowania, ale też z metafizycznego wymiaru naszych win i uznania, że wyrządzone zło nie tylko zaburza świat człowieka i relacji międzyludzkich, ale tak samo zaburza harmonię istnienia i doprowadza do chaosu. O tym pierwszym, czyli o metafizycznym wymiarze winy, pisał Karl Jaspers, wskazując, że jest: „solidarność między ludźmi jako ludźmi, na mocy której każdy obarczony jest współodpowiedzialnością za wszelkie zło i niesprawiedliwość na ziemi, a zwłaszcza za przestępstwa dokonane w jego obecności lub z jego wiedzą. Jeśli nie uczynię wszystkiego, co w mojej mocy, by im zapobiec, jestem współwinny"27. Ale nie dotyczy to tylko relacji międzyludz-

${ }^{24}$ Weil, Świadomość, 73.

25 Ricoeur, Symbolika, 76.

${ }^{26}$ Edyta Stein, Twierdza duchowa, tłum. Immakulata Adamska (Poznań: Zysk i S-ka, 1998), 66.

${ }^{27}$ Karl Jaspers, „Problem winy”, thum. Jan Garewicz, Etyka 17 (1979): 152-153. 
kich, lecz w ogóle relacji do istnienia. Doświadczają tego ludy pierwotne, u których na przykład przed ścięciem drzewa czy też zabiciem zwierzęcia pojawiała się prośba o przebaczenie tego czynu, skierowana w stronę drzewa lub zwierzęcia. A już Anaksymander podkreślał w swej filozofii, że nawet rzeczy ponoszą odpowiedzialność za zło. W tym sensie każdy człowiek jest współuczestnikiem czynionych krzywd, grzechów i zła. Jednym ze skutków zła jest ,rana zadana bytowi”, w której całościowy wymiar istnienia zostaje rozbity, człowiek zaś nie może dostrzec idei jednoczącej byt. Wszystko to oznacza, że nasze zło wcale nie jest tylko indywidualne i ludzkie, lecz zawsze jest metafizyczne i uniwersalne, dotyczące całego istnienia. I czyniąc krzywdę komuś, czynimy to przeciwko całemu Istnieniu.

W tym sensie przebaczenie jest wyrazem naszego uczestnictwa w kreacji nowego istnienia czy też ,istnienia na nowo". Przebaczenie jest pozytywnym wyjściem ze zła i ujawnieniem jakiejś wewnętrznej energii istnienia. Właśnie jemu powierzona jest największa siła pokonania zła. Można powiedzieć, że warunkiem możliwości istnienia jest przebaczenie i jego przemieniająca moc. Zło i grzech nie są konstruktywne, przeciwnie - są destrukcyjne dla istnienia. Jedynym sposobem zaś powstrzymania zła $\mathrm{w}$ istnieniu jest właśnie przebaczenie. Więcej nawet, powstrzymać destrukcję istnienia może tylko przebaczenie, do którego jest zdolny człowiek. Oznacza to, że właśnie na człowieku spoczywa ciężar możliwości przywrócenia istnieniu utraconego sensu. W pewnym sensie grzech, zło i wyrządzona krzywda oznaczają zawsze wzrost współczynnika negatywności w istnieniu. I dopiero przebaczenie przywraca harmonię i eliminuje chaos. Nie można zrozumieć tajemnicy istnienia bez uwzględnienia aktu przebaczenia.

Jeśli jednak każdy z nas ma swoją cząstkę winy, to i każdy z nas może uczestniczyć w przebaczeniu. Bóg dowiaduje się o winie Kaina $\mathrm{z}$ „całego świata”, bo cały świat woła o tym czynie. Oznacza to, że nie ma nigdy czystej winy prywatnej, ale i przebaczenie nie jest wcale sprawą prywatną. Nikt nie jest sam ze swoją winą i ze swoim przebaczeniem. Zło i wina człowieka nie jest tylko ,prywatnym przewinieniem”. Jest prawda, że odpowiadamy za siebie i własne czyny. Ale w jakiś sposób ponosimy też odpowiedzialność za czyny innych, chociaż nie mamy na nie wpływu.

Oczywiście o akty metafizycznego przebaczenia nie jest łatwo. Można nawet powiedzieć, że jest o nie znacznie trudniej niż o przebaczenie w wymiarze moralnym. Jakże często słyszy się: „Przebaczę jemu, jeśli zobaczę skruchę i usłyszę «przepraszam»". Tymczasem przebaczenie w wymiarze metafizycznym tego wcale nie potrzebuje. Potrzebuje za to współuczestnictwa i troski o byt. Pisał Gabriel Marcel: „Troszczę się o byt tylko o tyle, 
o ile bardziej lub mniej wyraźnie uświadamiam sobie ukrytąjedność, łącząca mnie z innymi bytami, których rzeczywistość przeczuwam"28. Do realizacji aktów tego metafizycznego przebaczenia potrzebne jest umniejszenie swojego ja na rzecz istnienia.

\section{Metafizyczne przebaczenie dzisiaj - utrata zmysłu grzechu}

I tu trzeba zapytać: dlaczego przebaczenie w tym wymiarze nie jest częstym aktem podejmowanym przez współczesnego człowieka? Należy podkreślić, że współczesny człowiek zwykle nie potrafi dostrzec metafizycznego sensu przebaczenia. Zbyt często ten akt staje się tylko ,aktem moralnym”, w którym chodzi o przywrócenie zgody. Człowiek naszej cywilizacji wydaje się o tym metafizycznym wymiarze zapominać. Nie dostrzega, że jednym ze skutków zła, krzywdy, grzechu jest „rana zadana bytowi”. Zamiast tego ma skłonność do ograniczania swego życia do własnej jednostkowej i na siebie zorientowanej egzystencji. Taka „orientacja na siebie”, chociaż nie musi przeszkadzać we właściwym rozpoznaniu dobra i zła, to jednak fałszuje reakcje na nie. Życie, w którym uczy się człowieka jedynie koncentracji na sobie i pomijania innych, może doprowadzić do rozwoju wielu ludzkich zdolności, lecz takie życie skutecznie zagradza drogę przed aktami poświęcenia i przebaczenia. „Trucizna subiektywizmu” - jak o niej mówi Clive Staples Lewis, oznacza przyjęcie, że „człowiek może dowolnie stwarzać wartości, że wspólnota ludzka może wybrać swoją ideologię, tak jak ludzie wybierają sobie ubrania" 29 . Egotycznie zorientowany człowiek nie jest skierowany ani w stronę poświęcenia, ani też przebaczenia. Zamiast tego ulega pokusie swego wyizolowania w każdym aspekcie życia. Im mocniejsza egocentryczna izolacja, tym więcej też podzielonego świata i mniej przebaczenia.

Człowiek współczesny ulega często „fałszywej metafizyce”, w której rozpoznanie „dobra i zła" myli z radykalnym rozdzieleniem, w którym po „,jednej stronie” sytuuje tylko dobro, ,po drugiej” tylko zło. Jeśli w tym rozróżnieniu można się zgodzić co do dobra (w dobru nie może być zła), to nie można się zgodzić, co do zła. Pisał św. Tomasz: „istnieją pewne dobra bez żadnej domieszki zła, natomiast nic nie jest do tego stopnia złe, żeby nie

${ }^{28}$ Gabriel Marcel, Tajemnica bytu, tłum. Małgorzata Frankiewicz (Kraków: Znak, 1995), 244.

${ }^{29}$ Clive Staples Lewis, Rozważania o chrześcijaństwie, tłum. Zbigniew Kościuk (Warszawa: Logos, 2002), 90. 
miało jakiejś domieszki dobra"30. Jeśli zatem coś istnieje, to z pewnością nie jest ono pozbawione dobra. Zrozumieć przebaczenie w sensie metafizycznym oznacza, że zawsze wtedy, gdy doświadczamy i spostrzegamy zło, to powinniśmy dostrzec również dobro, gdyż istnienie (nawet takie, o którym wydaje się nam, iż jest „samym złem”) nie jest jego pozbawione. I więcej nawet, to właśnie przebaczenie jest największą próbą ocalenia i wzmocnienia dobra w złu. Słowem: przebaczenie jest metafizyczną próbą ocalenia dobra w złu, które w nim zawsze jest. Ale też kultura współczesna wcale nie uczy przebaczać. Uczymy się wielu niepotrzebnych umiejętności, o tej zaś zapominamy. Jednak człowiek, który nie nauczy się tej umiejętności, przeżywa coś w rodzaju choroby, która dotyka jego ciała, umysłu i ducha. Trudno wtedy zrozumieć, że umiejętność ta leczy i przynosi korzyść. Jak jej jednak uczyć? Nauka nie jest łatwa, gdyż trzeba w niej zanegować to, czego uczy współczesna kultura: wszystko widzieć i wszystko mieć pod kontrolą. Tymczasem ,przebaczenie” w samej etymologii w języku polskim odwołuje się do innego sensu. Jest to: „przestać baczyć/patrzeć”. Czyli czegoś nie zauważać, coś pominąć, wobec czegoś przejść obok. Lecz czy my potrafimy jeszcze czasem być właśnie tacy?

\section{Zakończenie}

Dietrich Bonhoeffer w swoich „listach z więzienia” bardzo mocno podkreślał zagrażające człowiekowi niebezpieczeństwo odwrócenia się od świata i jego unieważnienia. „Nie wolno unieważniać przedwcześnie ziemskiego świata" ${ }^{31}$. Przebaczenie jest najlepszą drogą do pokonana tego zagrożenia. Przez nie zatrzymuje się przy człowieku i przy rzeczywistości, ale jest to zawsze inny człowiek i inna rzeczywistość. Wyrządzone zło i krzywda ustanawiają patologiczną relację z drugim człowiekiem. Ale ustanawiają również taką patologiczną relację z samym istnieniem, z całą rzeczywistością. Przebaczenie jest w stanie przywrócić właściwe wymiary tych relacji. Jeśli weźmiemy pod uwagę przedstawione dwie formy przebaczenia, to jasne się staje, że jego forma moralna jest możliwa tylko dzięki przebaczeniu metafizycznemu. To znaczy, tylko dlatego, że możemy przebaczać „,bezwarunko-

${ }^{30}$ Św. Tomasz z Akwinu, Kwestie dyskutowane o prawdzie, t. 2, thum. Adam Aduszkiewicz, Leszek Kuczyński, Jacek Ruszkowski (Kęty: Antyk, 1998), 46.

${ }^{31}$ Dietrich Bonhoeffer, Widerstand und Ergebung. Briefe und Aufzeichnungen aus der Haft. Herausgegeben von Eberhard Bethge (Berlin: Evangelische Verlagsanstalt, 1961), 226. 
wo", jako związani z całą rzeczywistością i za nią odpowiedzialni, możliwa jest jego postać moralna, w której akty przebaczenia wymagają przeprosin, skruchy i poczucia winy. Jednak odkrycie i nauczenie się ,przebaczenia metafizycznego" może pojawić się dopiero przez wzmocnienie moralnej formy przebaczenia zła, krzywdy i niesprawiedliwości. W nim właśnie - jak stwierdza Julia Kristeva - „wydobywa się spod czynu nieświadomość, która nie osądza, lecz słucha mojej prawdy ze względu na dostępność miłości, dlatego pozwala mi się narodzić na nowo"32.

W akcie przebaczenia splecione są trzy warunki: pierwszym jest znajomość dobra i zła. Ta znajomość konieczna jest zarówno po stronie tego, komu się przebacza, jak i tego, kto przebacza. W tym rozpoznaniu bowiem człowiek potwierdza siebie, przyjmując za siebie odpowiedzialność: jest odpowiedzialny przed sobą i przed kimś drugim. Drugim jest skrucha i poczucie winy. Człowiek wkracza w świat przebaczenia przez przeżycie winy i skruchę. Trzecim jest uświadomienie anormalnie rozrośniętej troski o siebie, zamknięcia się w sobie, egocentrycznej izolacji i otwarcie na całe istnienie. Wskazując te warunki przebaczenia, trzeba przyznać, że istnieją sytuacje zarówno sprzyjające temu, jak i przeszkadzające. Zaburzenia mogą dotyczyć każdego z nich. Bezsprzecznie żyjemy w świecie, w którym akty przebaczenia coraz bardziej tracą na znaczeniu. Dokładniej mówiąc, człowiek współczesny zapomniał o metafizycznym wymiarze przebaczenia i cały jego sens ogranicza do wymiaru moralnego. Trzeba jednak wyraźnie stwierdzić, że jak długo przebaczenie ograniczane jest do „spraw moralnych”, zachowania człowieka, tak długo też nie docieramy do jego pełnych treści. Właściwym miejscem pytania o przebaczenie i jego zrozumienie jest metafizyka, która wikła człowieka w problem całego istnienia, a nie tylko doświadczeń moralnych. Dopiero w związku z metafizyką jesteśmy w stanie dostrzec właściwy problem przebaczenia i jego roli już nie w życiu człowieka i społeczności, lecz samego istnienia. Troska o przebaczenie oznacza zatem konieczność zwrócenia się w zupełnie innym kierunku niż egocentryczna izolacja. „Mój byt - pisał Emmanuel Mounier - nie pokrywa się z moim życiem, jestem wcześniejszy od mego życia, nie wyczerpuje mnie ono, jestem ponad nim"33.

Na świecie jest wielu ludzi, którzy nie tylko nauczyli się przebaczać, lecz również takich, którzy tymi aktami ratują świat przed chaosem i de-

32 Julia Kristeva, Czarne słońce. Depresja i melancholia, thum. Michał Paweł Markowski, Remigiusz Ryziński (Kraków: Universitas, 2007), 204.

${ }^{33}$ Emanuel Mounier, Wprowadzenie do egzystencjalizmów oraz wybór innych prac, tłum. Ewa Krasnowolska (Kraków: Znak, 1964), 274. 
strukcją, potrafiąc tym samym przywrócić światu tyle dobra i miłości, ile odebrane mu zostało wraz ze złem. Człowiek winny i chaotyczny świat zdani są na przebaczenie. Trzeba to jednak dobrze zrozumieć. Nie chodzi o to, że ma prawo domagać się przebaczenia czy też może na nie liczyć. Nie, winny jest zdany na to, że pokrzywdzony zaoferuje jemu przebaczenie. Aktów przebaczenia nie można się domagać, można tylko na nie liczyć i można je przyjąć. Trzeba jednak też dobrze zrozumieć sytuację pokrzywdzonego, tego, który „może przebaczyć”. Przebaczając, pokrzywdzony przywraca winnego do człowieczeństwa, jest niczym Bóg, stwarzający człowieka na nowo. Czy może z tego nie skorzystać?

\section{Phenomenology of Forgiveness: Moral and Metaphysical Dimension of Forgiveness (Summary)}

The present paper is an attempt to give a phenomenological description of forgiveness. The author underlines an exceptional role that forgiveness plays in our, immersed in harm, guilt, evil and sin, culture. Without forgiveness such a world is in danger of destruction. Forgiveness is an action undertaken by a man in a specific situation. It is a situation of both harm and sense of guilt but also of resignation from a vengeance, from paying the perpetrator what he rightly deserves. The present paper analyses two dimensions of forgiveness. First is its moral dimension in which acts of forgiveness are caused by contriteness and atonement. Second is its metaphysical dimension in which unconditional forgiveness becomes possible. In both of these dimensions a transformation of man and being is accomplished.

Key words: forgiveness; transformation; harm; sin; new being.

\section{Fenomenologia przebaczenia - moralny i metafizyczny wymiar przebaczenia (Streszczenie)}

Artykuł jest próbą fenomenologicznego opisu przebaczenia. Autor podkreśla szczególną rolę przebaczenia w naszej kulturze, przepełnionej krzywdami, winami, złem, grzechem. Bez przebaczenia świat taki narażony jest na całkowitą destrukcję. Przebaczenie jest działaniem, aktywnością, jaką podejmuje człowiek w pewnej sytuacji. Jest to sytuacja krzywdy, poczucia winy, ale też rezygnacji z odpłacenia tym, 
co się krzywdzicielowi słusznie należy, rezygnacji z zemsty. W artykule poddaje się analizie dwa wymiary przebaczenia: pierwszym jest wymiar moralny, w którym akty przebaczenia uwarunkowane są skruchą i zadośćuczynieniem; drugim wymiar metafizyczny, w którym możliwe staje się przebaczenie bezwarunkowe. W obu wymiarach w przebaczeniu dokonuje się przemiany człowieka i przemiany bytu.

Słowa kluczowe: przebaczenie; przemiana; krzywda; grzech; nowy byt.

\section{Bibliografia}

Bonhoeffer, Dietrich. Widerstand und Ergebung. Briefe und Aufzeichnungen aus der Haft. Herausgegeben von Eberhard Bethge. Berlin: Evangelische Verlagsanstalt, 1961.

Cieszkowski, August. Ojcze nasz, t. 3. Poznań: Fiszer i Majewski, 1923.

Clendenen, Avis, Troy Martin. Uzdrawiajaca moc przebaczenia, thum. Jerzy Wolak. Kraków: WAM, 2004.

Grabowski, Marian. Krajobraz winy. Próba analizy fenomenologicznej. Toruń: Wydawnictwo UMK, 2001.

Hallowell, Edward M. Miej odwage wybaczyć, tłum. Monika Walendowska. Warszawa: Klub dla Ciebie, 2007.

Horney, Karen. Neurotyczna osobowość naszych czasów, tłum. Helena Grzegołowska. Warszawa: PWN, 1982.

Jaspers, Karl. „Problem winy”, tłum. Jan Garewicz. Etyka 17 (1979): 143-207.

Kendall, Robert Tillman. Przebaczyć do końca, tłum. Piotr Blumczyński. Katowice: Wydawnictwo Credo, 2006.

Kristeva, Julia. Czarne słońce. Depresja i melancholia, tłum. Michał Paweł Markowski, Remigiusz Ryziński. Kraków: Universitas, 2007.

Lewis, Clive Staples. Rozważania o chrześcijaństwie, tłum. Zbigniew Kościuk. Warszawa: Logos, 2002.

Marcel, Gabriel. Tajemnica bytu, thum. Małgorzata Frankiewicz. Kraków: Znak, 1995.

Margalit, Avishai. „Przebaczanie i zapominanie”, thum. Zofia Rosińska. Kronos 4 (2009): 150-160.

Mounier, Emanuel. Wprowadzenie do egzystencjalizmów oraz wybór innych prac, tłum. Ewa Krasnowolska. Kraków: Znak, 1964.

Platon. Gorgiasz, tłum. Paweł Siwek. Warszawa: PWN, 1991.

Prokofieff, Sergej O. Duchowe znaczenie przebaczenia, tłum. Michał Waśniewski. Gdynia: Genesis, 2006. 
Ricoeur, Paul. Symbolika zła, thum. Stanisław Cichowicz, Maryna Ochab. Warszawa: Instytut Wydawniczy PAX, 1986.

Sołowjow, Władimir. Uzasadnienie dobra. Filozofia moralna, tłum. Paweł Rojek, Marek Kita, Katarzyna Janowska, Leszek Augustyn. Kraków: Wydawnictwo UJ, 2005.

Soveringo, Giuseppe. Poczucie winy, tłum. Stanisław Obirek, Stanisław Pyszka. Kraków: M, 1993.

Spaemann, Robert. Szczęście a życzliwość. Eseje o etyce, thum. Jarosław Merecki. Lublin: Redakcja Wydawnictw KUL, 1997.

Stein, Edyta. Twierdza duchowa, tłum. Immakulata Adamska. Poznań: Zysk i S-ka, 1998.

Tillich, Paul. Rzeczywistość Chrystusa. Nowy byt, tłum. Jan Adrian Lata. Oleśnica: Oficyna Wydawnicza „Signum“, 1996.

Tomasz z Akwinu. Kwestie dyskutowane o prawdzie, t. 2, thum. Adam Aduszkiewicz, Leszek Kuczyński, Jacek Ruszkowski. Kęty: Antyk, 1998.

Weil, Simone. Świadomość nadprzyrodzona. Wybór myśli, thum. Aleksandra Olędzka-Frybesowa. Warszawa: Instytut Wydawniczy PAX, 1986.

Wiesenthal, Simon. Die Sonnenblume. Von Schuld und Vergebung. Paris: Opera Mundi, 1969.

Wiesenthal, Szymon. Stonecznik. Opowieść i komentarze, thum. Magdalena Kurkowska, Katarzyna Sendecka. Warszawa: Państwowy Instytut Wydawniczy, 2000 . 